Original Scientific Paper

\title{
Development of the Textile Industry in Selected Transition Countries of Europe in 1995-2018
}

\author{
Article history: \\ Received: 3 March 2021 \\ Sent for revision: 18 March 2021 \\ Received in revised form: 7 May 2021 \\ Accepted: 18 May 2021 \\ Available online: 10 December 202
}

\begin{abstract}
The paper examines the development of the textile industry in nine selected European countries in transition (Bosnia and Herzegovina, Bulgaria, Croatia, the Czech Republic, Hungary, North Macedonia, Romania, Serbia and Slovenia) in the period from 1995 to 2018. The aim is to review the basic trends in the development of the textile industry in these countries by achieving the transition to a market model of business with varying degrees of success, which, among other things, is accompanied by a strong wave of deindustrialization. The interdependence of Textiles and clothing industry value added in manufacturing and GDP pc levels in individual countries was calculated by the exponential correlation procedure. It was stated that these countries based their development in the transition period largely on strengthening trade competitiveness, with the textile industry (Textile fibers, yarn, fabrics and clothing) contributing to a significant export expansion. It turned out that the contribution of the textile industry to the economic growth of the analyzed economies was higher in the earlier stages of their economic development. Also, the results of the research confirmed that the textile industry in these countries has maximized its export potential at lower levels of their GDP pc.
\end{abstract}

\footnotetext{
${ }^{1}$ Academy of Technical and Art Applied Studies Belgrade, Serbia

2 University of Belgrade, Faculty of Organizational Sciences

${ }^{3}$ University of Niš, Faculty of Economics

${ }^{4}$ University of Kragujevac, Faculty of Economics, ddespotovic@kg.ac.rs
} 
Keywords: textile industry, development, competitiveness, countries in transition.

\title{
Razvoj tekstilne industrije u izabranim tranzicionim evropskim zemljama u periodu od 1995 do 2018.
}

\begin{abstract}
Apstrakt: $U$ radu se ispituje razvoj tekstilne industrije $u$ devet selektovanih evropskih zemalja u tranziciji (Bosne i Hercegovine, Bugarske, Hrvatske, Češke, Mađarske, Severne Makedonije, Rumunije, Srbije i Slovenija) u periodu od 1995. do 2018. godine. Cilj je sagledavanje osnovnih trendova u razvoju tekstilne industrije u ovim zemljama koje su sa različitim uspehom ostvarile prelaz na tržišni model privređivanja koji je pored ostalog praćen snažnim talasom deindustrijalizacije. Međuzavisnost učešća dodatne vrednosti tekstilne i odevne industrije u proizvodnji i nivou BDP po stanovniku u pojedinim zemljama je izračunata postupkom eksponencijalne korelacije. Konstatovano je da su svoj razvoj u tranzicionom periodu ove zemlje u velikoj meri zasnivale na jačanju trgovinske konkurentnosti, pri čemu je značajnoj izvoznoj ekspanziji u velikoj meri doprineo i sektor tekstilne industrije (Tekstilna vlakna, predivo, tkanine i odeća). Ispostavilo se da je doprinos tekstilne industrije privrednom rastu analiziranih privreda bio veći u ranijim fazama njihovog ekonomskog razvoja. Takođe, rezultati istraživanja su potvrdili da je tekstilna industrija u ovim zemljama svoj izvozni potencijal maksimizirala na nižim nivoima njihovog BDP po stanovniku.
\end{abstract}

Ključne reči: tekstilna industrija, razvoj, konkurentnost, zemlje u tranziciji.

\section{Introduction}

The production of various types of clothing (first primitive, and over time increasingly complex) is, along with food production, probably the oldest human activity. Also, the textile industry is an activity that played a very important role in the early phase of industrialization, first in the countries that were first affected by the industrial revolution (e.g., Great Britain and other Western European countries), and later in other countries during their industrial development (Gligorijević, 2019). Although the importance and influence of the textile industry in most industrialized countries has declined over time, in many countries the textile industry still plays an important role in gross domestic product (GDP) (Yang \& Zhong, 1998), and in employment through hiring a significant share of available labor (over $70 \%$ of employees are women) achieving positive export balances (Adhikari \& Yamamoto (2007). 
Although the textile industry is a significant activity in many countries around the world, transition processes have led to the textile industry significantly reducing its share in GDP creation in most transition economies. To a large extent, this is the result of a kind of marginalization and pronounced deindustrialization that occurred in these countries during the transition process (Ćorović, Gligorijevi, \& Kostadinović, 2020). However, research has confirmed that the textile industry in many transition economies has a significant export potential quantified by the share of the value of textile industry exports in total exports (Gligorijević \& Ćorović, 2020).

The aim of the research in this paper is to examine the development of the textile industry in these countries, which have achieved the transition to a market model of business with varying degrees of success, which is accompanied by a strong wave of deindustrialization.

Starting from the subject and goal of the research, after the introduction, the paper gives an overview of the used material and applied research methods, as well as the results with discussion. The paper is completed by concluding remarks.

\section{Materials and Research Methods}

The subject of research in this paper is the development of the textile industry in nine selected European countries in transition (Bosnia and Herzegovina, Bulgaria, Croatia, the Czech Republic, Hungary, North Macedonia, Romania, Serbia and Slovenia) in the period 1995-2018. Some of these countries are among the most successful transition economies (the Czech Republic, Slovenia and Hungary), others can be marked as successful thanks to which they became members of the EU (Croatia, Bulgaria, Romania), while Bosnia and Herzegovina, North Macedonia, and Serbia can be marked as countries of so-called delayed transitions (Figure 1). 
Figure 1. Groups of observed countries by level of economic development

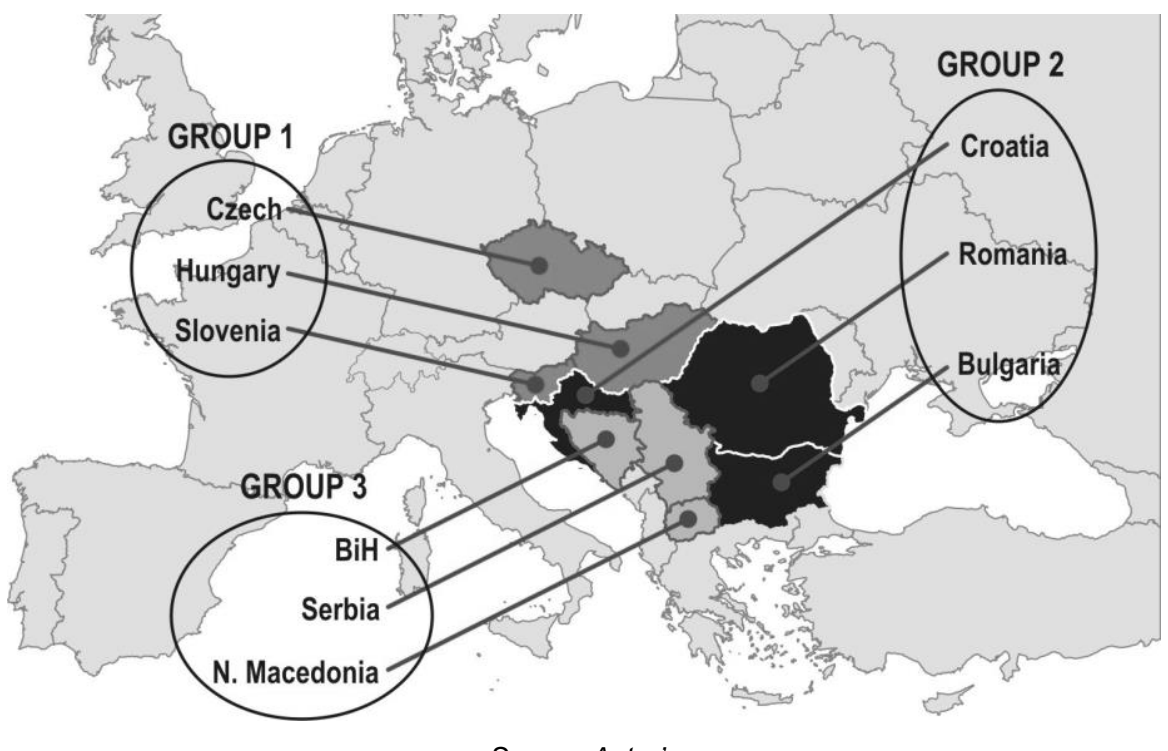

Source: Autor's

The material for conducting the necessary analyzes was obtained through secondary research and it is based on the analysis of the available scientific literature that deals with the research of various aspects of the development of the textile industry. When choosing research methods and techniques, we started from the fact that this is a "mature" industrial activity that undergoes significant changes over time (Ćorović, Jovanović, \& Ristić, 2013).

These structural changes that the textile industry is going through are indicated by Kathuria (2001) who points out that these changes within the textile industry occur due to the constant introduction of innovations in the direct production process (Fig. 2) due to the reduction of production costs on that basis and the emergence of new significant international competitors (Fischer, \& Pascucci, 2017; Ku, Chien, \& Ma, 2020; Lin, \& Bai, 2020; Despotovic, Cvetanović, \& Nedić, 2014). 
Figure 2. The importance of innovation-driven textile research and development in the textile industry

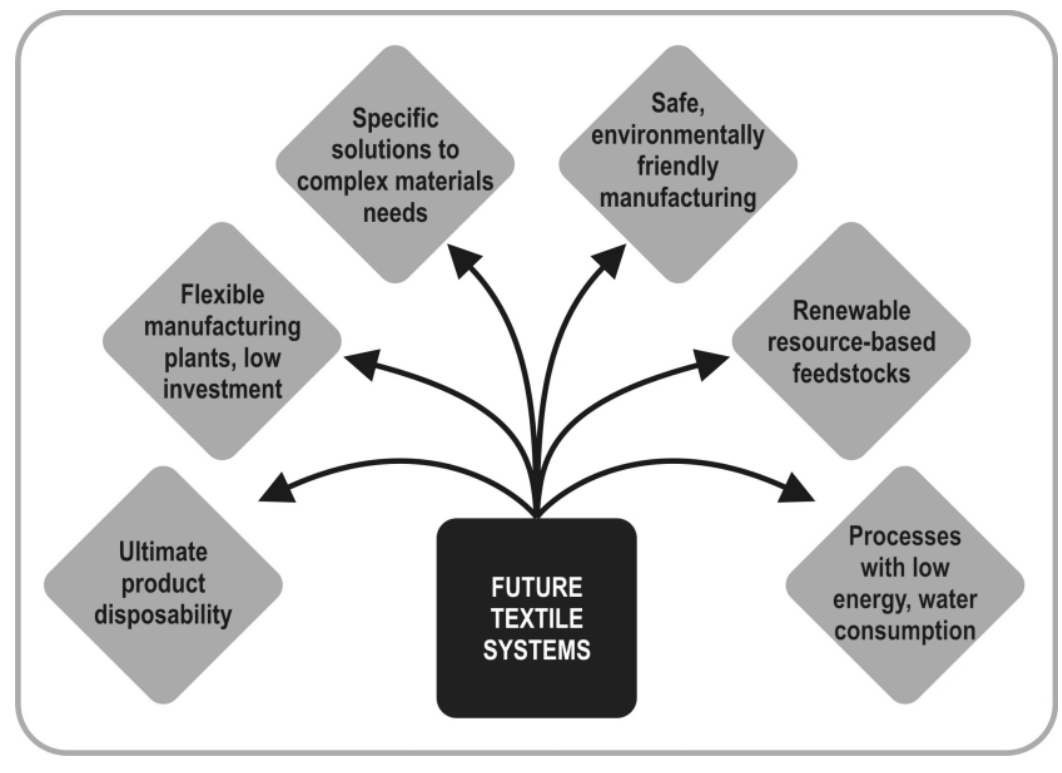

Source: authors based on Shishoo, 2012.

Rapid technological development through constant innovation is a typical determinant of the modern textile industry. Equipment (machines) is becoming more complex, automated and digitized. The job description of employees in the textile industry is changing so that workers are less involved in the direct production and realization of other production tasks, and are increasingly engaged in the development, design, marketing and supervision of the overall production and business process. Numerous competitors from abroad appear on the domestic markets, while consumers have become more demanding, especially when it comes to fashion trends and the ratio of price and quality. (FIT, 2017, p. 2)

A significant change in the field of textile industry on a global level occurred after 2005, when the abolition of the trade quota system led to the reduction and elimination of trade barriers in this highly protected production area (Ćorović, 2012). The existence of various forms of trade restrictions until that period enabled the most industrially developed countries to dictate the conditions in the global business of the textile industry, as a rule to the detriment of less developed countries that had to operate under these less favorable conditions. This is indicated by Adhikari, \& Yamamoto (2007) who point out that the abolition of trade quotas, among other factors, has led to an 
acceleration of concentration of production within the textile industry through strong development of multinational textile companies, which carry out various business activities in many countries by using the comparative advantages of each individual country to maintain and increase the existing level of competitiveness.

Many well-known companies in the textile industry have resorted to the system of subcontracting - outsourcing or relocating part of business activities in countries with lower operating costs and more liberal regulation. This, in turn, marked the relocation of production and employment from developed to less developed countries, including some countries in transition, such as Serbia, Bosnia and Herzegovina and North Macedonia (Kostić, Milutinović \& Nikolić, 2018, p. 487). These processes are accompanied by the disappearance of old, well-known companies and the emergence of new fastgrowing companies in the field of textile industry, mostly in countries with dynamic development.

Sudden and premature deindustrialization, implemented transitional reforms and implemented economic development strategy, have led to the devastation of industry in almost all transition economies. Therefore, in order to ensure a sustainable level of GDP per capita, a strategy of their re-industrialization is imposed. (Mićić, 2015).

The textile industry in transition countries has a long tradition. With the collapse of socialism, it is certain that the loss of the market and the growing import of cheap textile products from Asian countries were a major blow to its development. Only finishing works with the countries of the European Union contributed to slowing down the decline of the textile industry in these countries. At the same time, transition economies such as Slovenia, Hungary, and the Czech Republic have gradually ceded production in the textile sector to less developed transition countries (Rošević et al., 2009, 99). However, despite the marginal share in the creation of gross domestic product, this industrial area is recording satisfactory export results in these countries (Gligorijević \& Ćorović, 2020).

In the second decade of the 21 st century sources of competitive advantage of the textile industry are predominantly based on quality, modern product design, production of technically demanding products and flexible delivery (Ćorović, 2012; Ćorović, Gligorijevic, \& Kostadinović, 2020).

That is why economically developed economies have tried to move the production of traditional textile products to countries with cheaper production costs, among which a special place on European soil belongs to the countries of the so-called delayed transitions. 
In order to examine the development of the textile industry in nine selected European countries in transition in the period 1995-2018, the following hypotheses were set:

$\mathrm{H} 1$ : The contribution of the textile industry to GDP pc in transition countries decreases proportionally with GDP pc growth.

$\mathrm{H} 2$ : There is relatively higher share of Textiles and clothing value in the structure of total exports in countries with lower levels of GDP pc.

Development indicators (GDP per capita, share manufacturing in GDP, share textiles and clothing in manufacturing and Value index of exports) on the example of 9 countries in transition in the period 1995-2018 were calculated based on data from the World Bank database of World Development Indicators (World Bank, n.d.).

\section{Results and discussion}

After several initial years, political and economic, transitional processes, in 1995 the former so-called socialist countries were at different levels of economic development, measured on the basis of GDP pc (constant 2010 US $\$$ ). The most economically developed (out of 9 observed) countries in transition were Slovenia and the Czech Republic, and above the world average GDP pc were also Hungary and Croatia, while Romania, Bulgaria, Serbia, North Macedonia and Bosnia and Herzegovina lagged behind not only the EU average but also for the world average (Table 1).

Table 1. GDP per capita selected countries in transition in 1995 and 2018.

\begin{tabular}{|l|r|r|c|c|c|}
\hline \multirow{2}{*}{} & \multicolumn{1}{|c|}{$\mathbf{1 9 9 5}$} & \multicolumn{1}{c|}{$\mathbf{2 0 1 8}$} & \multicolumn{2}{c|}{$\mathbf{2 0 1 8 - 1 9 9 5}$} \\
\cline { 2 - 6 } & $\begin{array}{c}\text { Value } \\
\text { (in constant } 2010 \\
\text { US } \$ \text { ) }\end{array}$ & $\begin{array}{c}\text { change in value } \\
\text { (absolute growth) }\end{array}$ & $\begin{array}{c}\text { y/y } \\
\text { (in \%) }\end{array}$ & $\begin{array}{c}\text { CAGR } \\
\text { (in \%) }\end{array}$ \\
\hline Bulgaria & 4.283 & 8.671 & 4.387 & 102,4 & 3,1 \\
\hline BiH & 871 & 6.037 & 5.166 & 593,0 & 8,8 \\
\hline Croatia & 8.568 & 15.906 & 7.337 & 85,6 & 2,7 \\
\hline Hungary & 8.958 & 16.636 & 7.679 & 85,7 & 2,7 \\
\hline N.Macedonia & 3.057 & 5.442 & 2.386 & 78,0 & 2,5 \\
\hline Romania & 4.900 & 11.586 & 6.687 & 136,5 & 3,8 \\
\hline Serbia & 3.064 & 6.886 & 3.822 & 124,7 & 3,6 \\
\hline Slovenia & 15.142 & 26.684 & 11.542 & 76,2 & 2,5 \\
\hline Czech R. & 13.463 & 23.324 & 9.861 & 73,2 & 2,4 \\
\hline EU & 25.825 & 36.608 & 10.783 & 41,8 & 1,5 \\
\hline World & 7.387 & 10.919 & 3.532 & 47,8 & 1,7 \\
\hline${ }^{*}$ Compound Annual Growth Rate - CAGR & & & \\
\hline
\end{tabular}

Source: authors based on World Bank database: World Development Indicators, https://data.worldbank.org/indicator

Industrija, Vol.49, No.2, 2021 
In 2018, after more than 20 years of transition processes, the observed European countries recorded more pronounced GDP per capita growth compared to the average GDP per capita growth in the EU (1.5\% CAGR) and in the world (1.7\% CAGR). Relatively fast growth has enabled these countries to reduce the lag in the level of GDP per capita compared to the EU average (so-called economic convergence), and Romania in addition to Slovenia, the Czech Republic, Hungary and Croatia to be above the world average in terms of GDP pc (Fig. 3).

Figure 3. GDP per capita selected countries in 1995 and 2018

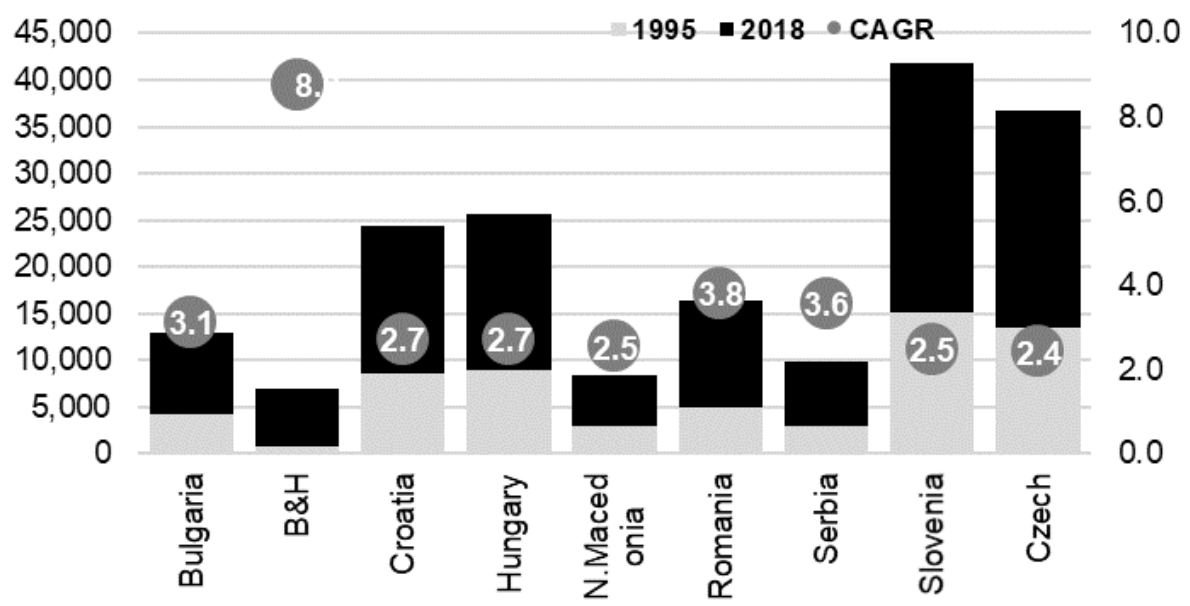

Source: authors based on World Bank database: World Development Indicators, https://data.worldbank.org/indicator

Compared to 1995, the most dynamic average GDP growth per capita was recorded in Bosnia and Herzegovina (8.8\% CAGR), Romania (3.8\% CAGR), Serbia and Bulgaria (3.6\% and 3.1\% CAGR). However, such high GDP per capita growth rates for Bosnia and Herzegovina and Serbia are largely the result of a low starting base because these countries were in very difficult economic conditions in 1995 (Bosnia and Herzegovina in a state of war, and Serbia in conditions of economic sanctions). The slowest GDP per capita growth in the observed period was recorded by North Macedonia, Slovenia and the Czech Republic. Countries such as Bulgaria, Serbia, Bosnia and Herzegovina and North Macedonia, although recording dynamic GDP per capita growth, have not yet managed to surpass the world average in terms of GDP levels and are still relatively far from the EU average. 
The relatively rapid economic growth of GDP of the observed countries in transition was accompanied by a pronounced trend of deindustrialization in the period 1995-2018 in most of the observed countries (Serbia, North Macedonia, Croatia, Romania and Slovenia). In contrast to these countries, Bosnia and Herzegovina, the Czech Republic and Hungary strengthened their Manufacturing and increased its share in the economy (in GDP creation) (Table 2).

Table 2. Share Manufacturing in GDP and Textiles and clothing in manufacturing in 1995-2018

\begin{tabular}{|c|c|c|c|c|c|c|}
\hline & \multicolumn{3}{|c|}{$\begin{array}{l}\text { Manufacturing, value added } \\
\text { (\% of GDP) }\end{array}$} & \multicolumn{3}{|c|}{$\begin{array}{l}\text { Textiles and clothing } \\
\text { (\% of value added in } \\
\text { manufacturing) }\end{array}$} \\
\hline & 1995 & 2018 & $\begin{array}{c}\% \\
\text { change } \\
\end{array}$ & 1995 & 2018 & $\begin{array}{c}\% \\
\text { change } \\
\end{array}$ \\
\hline $\mathrm{BiH}$ & 11,44 & 13,23 & 1,79 & $12,54^{2}$ & 12,59 & 0,05 \\
\hline Bulgaria &.. &.. & & $11,77^{3)}$ & 10,45 & $-1,32$ \\
\hline Croatia & 18,54 & 12,52 & $-6,02$ & 12,44 & 5,08 & $-7,36$ \\
\hline Hungary & 18,19 & 18,64 & 0,45 & 8,07 & 2,11 & $-5,97$ \\
\hline N. Macedonia & 18,66 & $12,60^{1)}$ & $-6,06$ & 14,67 & 18,87 & 4,20 \\
\hline Romania & 23,87 & 18,71 & $-5,16$ & 12,71 & 10,15 & $-2,57$ \\
\hline Serbia & 23,47 & 14,51 & $-8,96$ & $6,13^{4)}$ & 7,32 & 1,19 \\
\hline Slovenia & 21,57 & 20,43 & $-1,15$ & 14,35 & 2,35 & $-12,00$ \\
\hline Czech R. & 21,53 & 23,08 & 1,55 & $7,24^{5)}$ & $2,54^{6)}$ & $-4,70$ \\
\hline
\end{tabular}

Source: authors based on World Bank database: World Development Indicators, https://data.worldbank.org/indicator

Slightly different trends were noted in terms of the importance of Textiles and clothing in creating value added in manufacturing, i.e., the economy as a whole. At the beginning of the period (in 1995, except for Bulgaria and the Czech Republic - 1996, Bosnia and Herzegovina -2010 and Serbia - 2002) the largest share of Textiles and clothing in the creation of value added in manufacturing had North Macedonia, Slovenia (above 14\%), then Romania, Bosnia and Herzegovina, Croatia (above 12\%) and Bulgaria (11.77\%), and least Serbia (6.13\%), the Czech Republic (7.24\%) and Hungary (8.07\%).

At the end of the observed period (in 2018, except for the Czech Republic 2013), the largest share of Textiles and clothing in value added in manufacturing was recorded by North Macedonia (18.87\%), Bosnia and Herzegovina (12.59\%), Bulgaria (10,45\%) and Romania (10.15\%), followed by Serbia (7.32\%) and Croatia (5.08\%), while the Czech Republic (2.54\%)

Industrija, Vol.49, No.2, 2021 
have the lowest share of Textiles and clothing in value added in manufacturing), Slovenia (2.35\%) and Hungary (2.11\%).

Observing the participation of Textiles and clothing in value added in manufacturing at the beginning and end of the observed period, it can be noticed that only two countries (North Macedonia - 4.20 pp and Serbia - 1.19 pp) increased the participation. In Bosnia and Herzegovina, this share remained at approximately the same level, while in the other five countries the share of Textiles and clothing in value added in manufacturing decreased (the highest in Slovenia by $-12.00 \mathrm{pp}$, and the lowest in Bulgaria by $-1.32 \mathrm{pp}$ ), which indicates a decline in the importance of Textiles and clothing in these economies (Fig. 4).

Figure 4. Change share Manufacturing in GDP and Textiles and clothing of value added in manufacturing

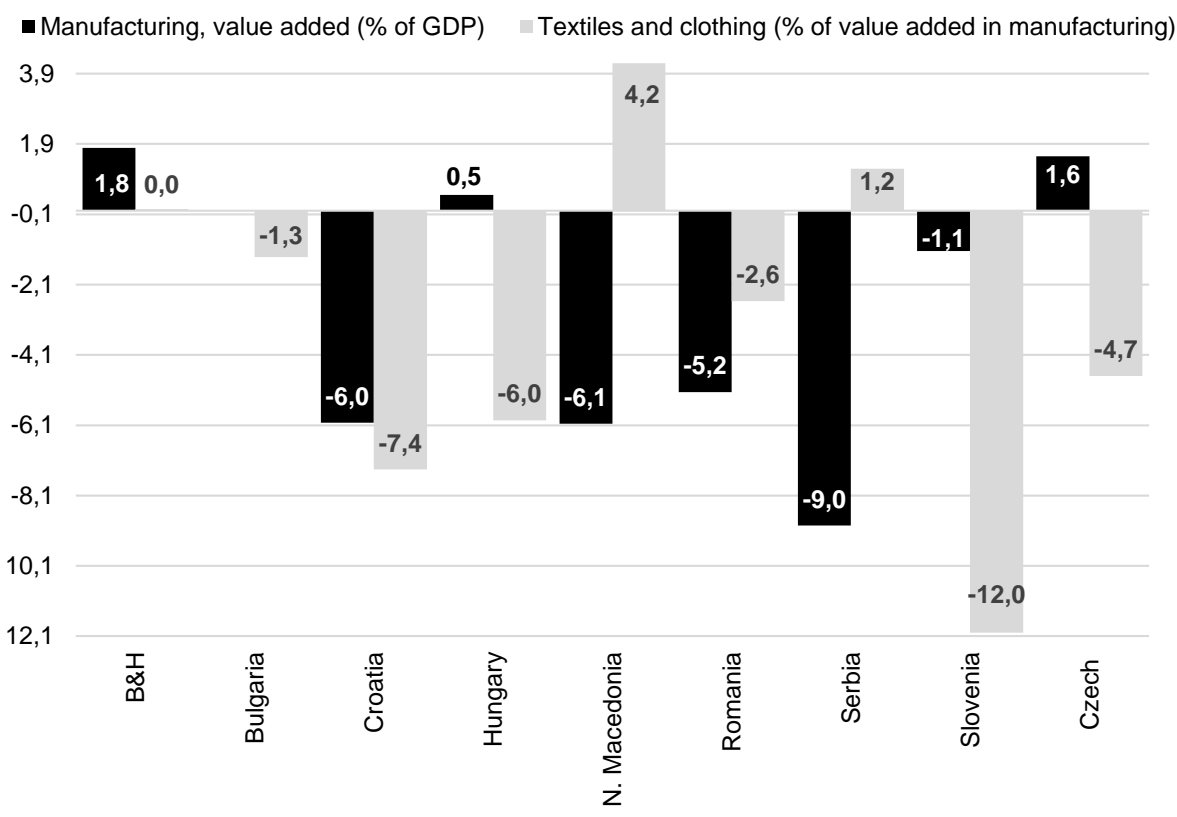

Source: authors based on World Bank database: World Development Indicators, https://data.worldbank.org/indicator

The situation is particularly negative in Hungary and the Czech Republic, where the growth of the share of Manufacturing in GDP (of +0.45 and 1.55 pp, 
respectively) was followed by the decline of the share of Textiles and clothing in value added in manufacturing (of -5.97 and $-4.70 \mathrm{pp}$ respectively).

Figure 5 shows the interdependence of Textiles and clothing industry value added in manufacturing on GDP pc, obtained by the exponential correlation procedure. By analyzing the relation shown in Figure 5, a significant value of the Pearson correlation coefficient $R^{2} / R=0.52 / 0.72$ can be detected, which is significantly higher than the limit value of 0.25 for a significance level of $1 \%$. Based on these results, it can be concluded that the textile industry significantly contributes to GDP growth in the early stages of economic development. Its impact is relatively declining with the growth of the GDP pc and its approach to the EU average.

Figure 5. Correlation analysis of observed countries for GDP per capita and Textiles and clothing \% of value added

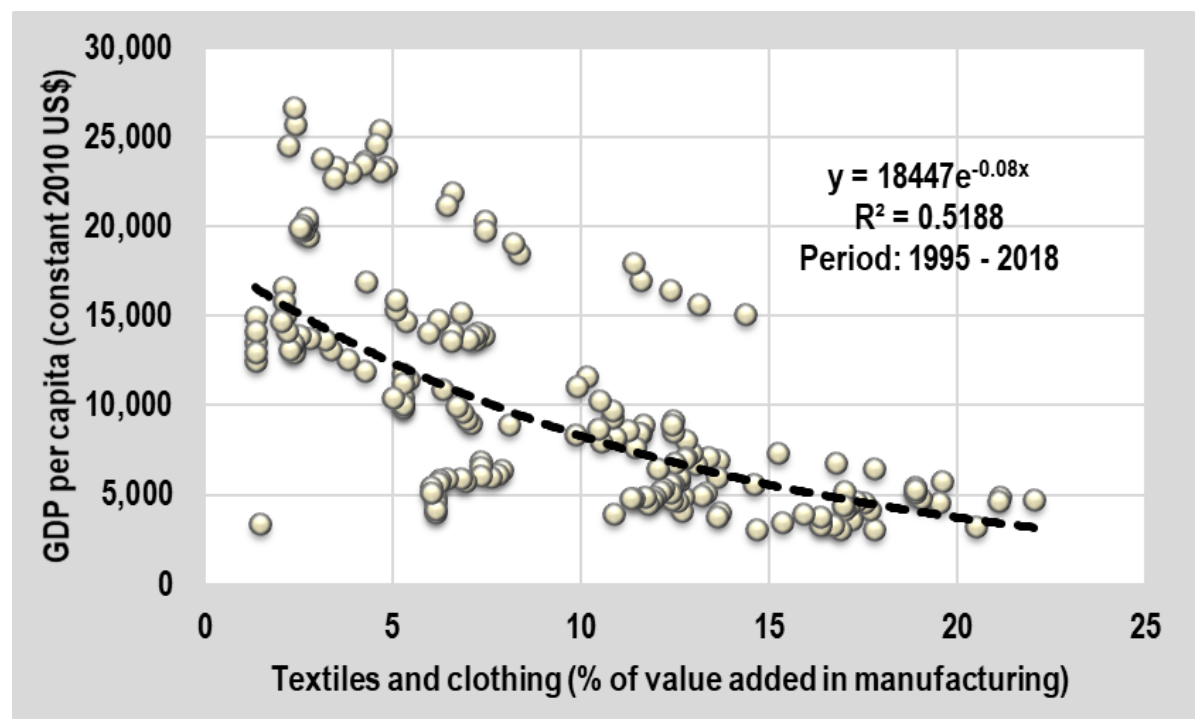

Source: authors based on World Bank database: World Development Indicators, https://data.worldbank.org/indicator

In addition to changes in terms of dynamics and structure of economic growth of the observed countries in the period 1995-2018 there has also been a significant change in the foreign trade of these countries. In particular, there has been a dynamic growth in the value of exports of these countries (measured by the Value index of exports) and an increase in the importance of exports of goods and services in creating GDP (Fig. 6). 
Figure 6. Value index of exports of selected countries in 2018 (Index Base 2000)

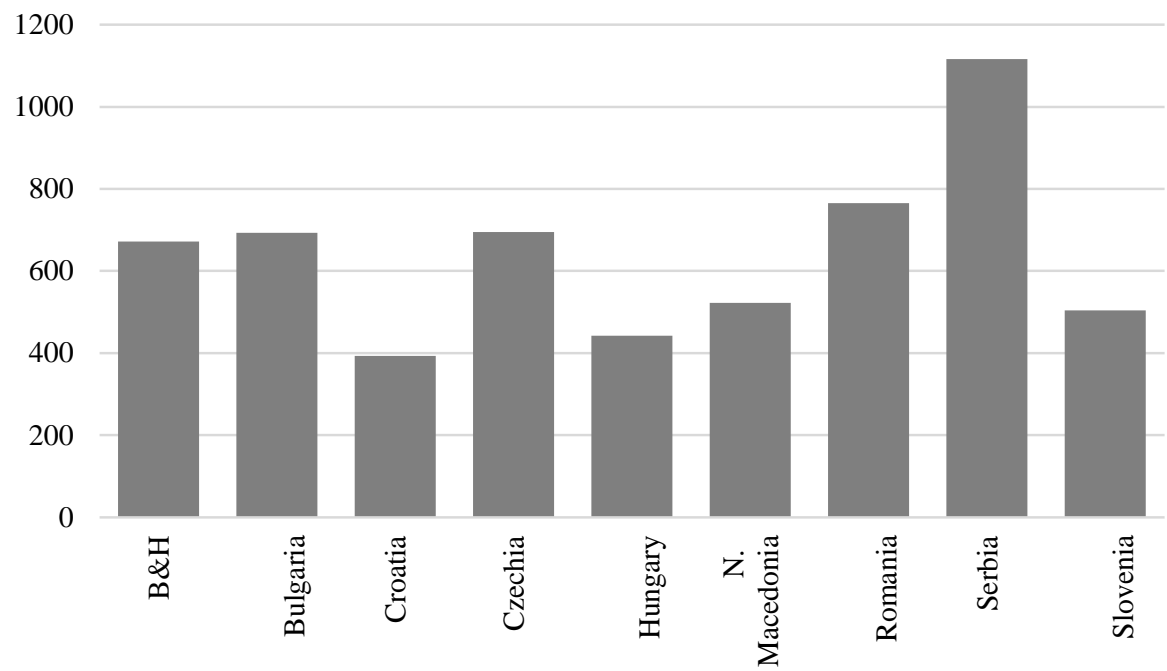

Source: authors based on World Bank database: World Development Indicators, https://data.worldbank.org/indicator

In 2018, out of 9 selected countries in transition, the highest growth of exports, measured by the Value index of exports, compared to the base year 2000 , was achieved by Serbia (11.2 times growth of the index value), followed by Romania (7.7 times), the Czech Republic (7.0 times) and Bulgaria and Bosnia and Herzegovina (6.9 and 6.7 times, respectively). Slightly more modest growth in the value of exports was recorded by North Macedonia (5.2 times) and Slovenia (5.0 times), and the smallest growth was recorded by Hungary (4.4 times) and Croatia (3.9 times).

The strong growth in the value of exports also influenced the change in the share of exports of goods and services in GDP (Fig. 7). In 1995, the largest share of exports of goods and services in GDP had three most developed countries in transition (out of 9 observed): Slovenia (45.4\%), the Czech Republic (40.4\%) and Hungary (39.2\%), followed by Bulgaria, North Macedonia, Croatia and Romania. As expected, Bosnia and Herzegovina and Serbia had the lowest share of exports in GDP due to war and sanctions. 
Figure 7. Exports of goods and services (\% of GDP) of selected countries in 1995 and 2018

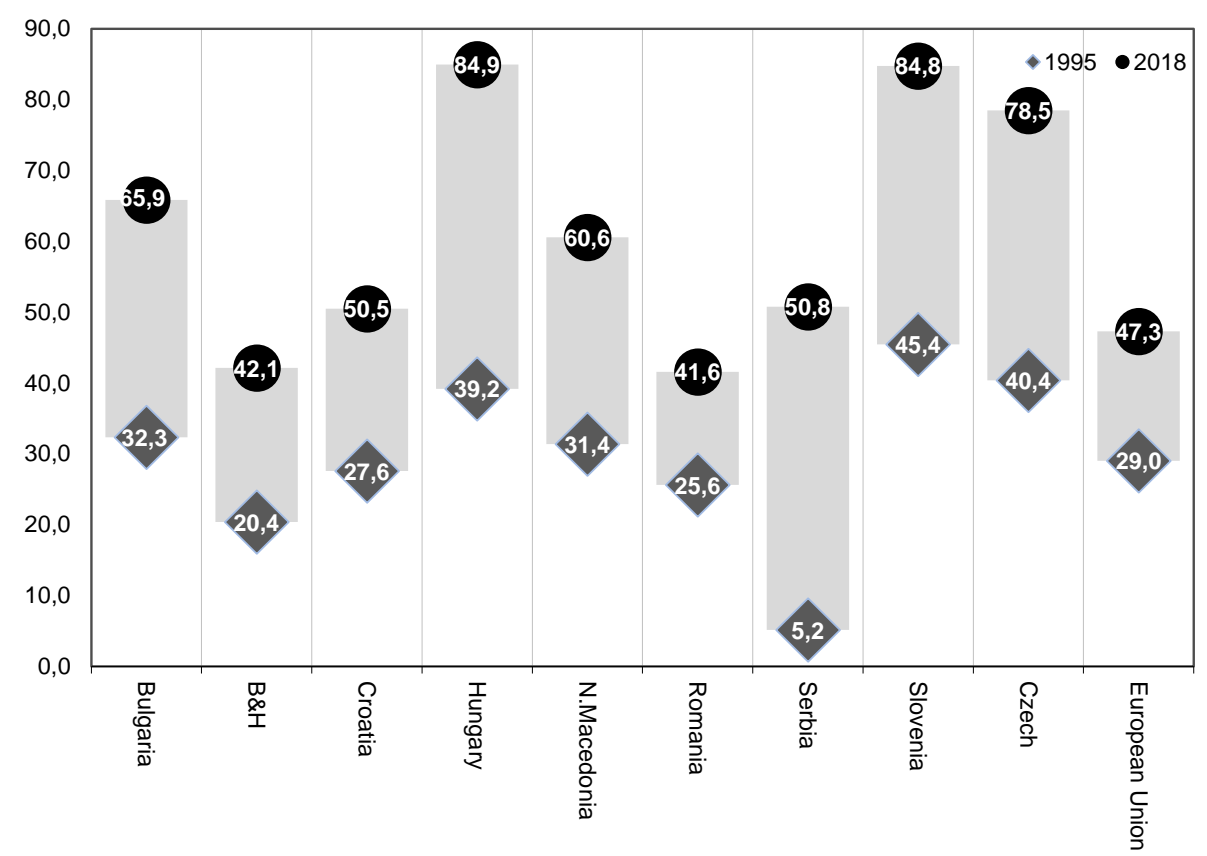

Source: authors based on World Bank database: World Development Indicators, https://data.worldbank.org/indicator

All observed countries have significantly increased the share of exports of goods and services in GDP in the two decades of transition. The largest increases were recorded in Hungary (45.8 percentage points), Serbia (45.6 $\mathrm{pp})$, Slovenia (39.3 pp) and the Czech Republic (38.1 pp), to a lesser extent in Bulgaria (33.5 pp) and North Macedonia (29.2 pp), and the lowest growth of the share of exports in GDP was realized in Croatia (22.9 pp), Bosnia and Herzegovina (21.7 pp) and Romania (16.0 pp). Accordingly, in 2018, the largest share of exports of goods and services in GDP have Hungary $(84.9 \%)$, Slovenia (84.8\%) and the Czech Republic (78.5\%), as well as the three most developed countries of the observed countries in transition, which indicates that their development in the transition period of these countries was largely based on strengthening trade competitiveness. Bulgaria (65.9\%) and North Macedonia $(60.6 \%)$ also have a significant share of exports of goods and services in GDP in 2018, while Serbia (50.8\%) and Croatia have a slightly 
smaller share, with Bosnia and Herzegovina (42.1\%) and Romania (41.6\%) having the lowest share.

The textile industry sector (Textile fibers, yarn, fabrics and clothing, Table 3) also contributed significantly to the significant export expansion of the observed countries (except Slovenia).

Table 3. Export textile industry of selected countries in 1995 and 2018

\begin{tabular}{|l|c|c|c|c|c|}
\hline \multirow{2}{*}{} & $\mathbf{1 9 9 5}$ & $\mathbf{2 0 1 8}$ & \multicolumn{2}{c|}{$\mathbf{1 9 9 5 - 2 0 1 8}$} \\
\cline { 2 - 6 } & \multicolumn{2}{|c|}{$\begin{array}{c}\text { Value } \\
\text { (in million US\$) }\end{array}$} & $\begin{array}{c}\text { change in value } \\
\text { (absolute growth) }\end{array}$ & $\begin{array}{c}\text { y/y } \\
\text { (in \%) }\end{array}$ & $\begin{array}{c}\text { CAGR } \\
\text { (in \%) }\end{array}$ \\
\hline BiH & 13,0 & 495,3 & 482,4 & $3.723,7$ & 17,2 \\
\hline Bulgaria & 534,7 & $2.340,2$ & $1.805,5$ & 337,7 & 6,6 \\
\hline Croatia & 803,7 & $1.066,9$ & 263,2 & 32,8 & 1,2 \\
\hline Hungary & $1.340,7$ & $1.753,3$ & 412,6 & 30,8 & 1,2 \\
\hline N. Macedonia & 212,1 & 633,5 & 421,4 & 198,7 & 4,9 \\
\hline Romania & $1.598,9$ & $4.878,7$ & $3.279,8$ & 205,1 & 5,0 \\
\hline Serbia & 91,0 & 980,0 & 889,0 & 977,2 & 10,9 \\
\hline Slovenia & 983,3 & 932,5 & $-50,8$ & $-5,2$ & $-0,2$ \\
\hline Czech R. & $1.673,1$ & $6.777,9$ & $5.104,8$ & 305,1 & 6,3 \\
\hline
\end{tabular}

Source: authors based on World Bank database: World Development Indicators, https://data.worldbank.org/indicator

In the period 1995-2018, exports of textile products from the observed countries were realized in all countries except Slovenia, where a decline in exports amounted to EUR 50.8 million $(-5.2 \%)$. The largest increase in the value of textile industry exports in the period 1995-2018 was recorded by the Czech Republic (US \$ 5.1 trillion growth) and Romania (US \$ +3.3 trillion), followed by Bulgaria (US $\$ 1.8$ billion) and Serbia (US $\$+889.0$ million). The value of exports also increased in Bosnia and Herzegovina, North Macedonia, Hungary and Croatia, but to a lesser extent.

According to the growth rate of exports, the export of textile industry in the observed period increased the most in Bosnia and Herzegovina (17.2\% CAGR) and Serbia (10.9\% CAGR), although this growth should take into account the low starting base of the observed countries in 1995. Relatively fast growth of the textile industry in the period 1995-2018 was recorded by Bulgaria (6.6\% CAGR), the Czech Republic (6.3\% CAGR), Romania (5.0\% CAGR) and North Macedonia (4.9\% CAGR). The growth of exports, although much more modest, was also recorded in Croatia and Hungary (1.2\% CAGR), and the decline in exports of the textile industry was recorded only in Slovenia $(-0.2 \%$ CAGR $)$. 
In the figure (Fig. 8), the interdependence of Textiles and clothing industry Export Product Share and GDP pc, obtained by the logarithmic correlation procedure, was examined. Accordingly, a significant value of the Pearson correlation coefficient $R^{2} / R=0.38 / 0.62$ can be detected, which is significantly higher than the limit value of 0.25 for a significance level of $1 \%$.

Figure 8. Correlation analysis of observed countries for GDP per capita and Textiles and clothing \% of Export product share

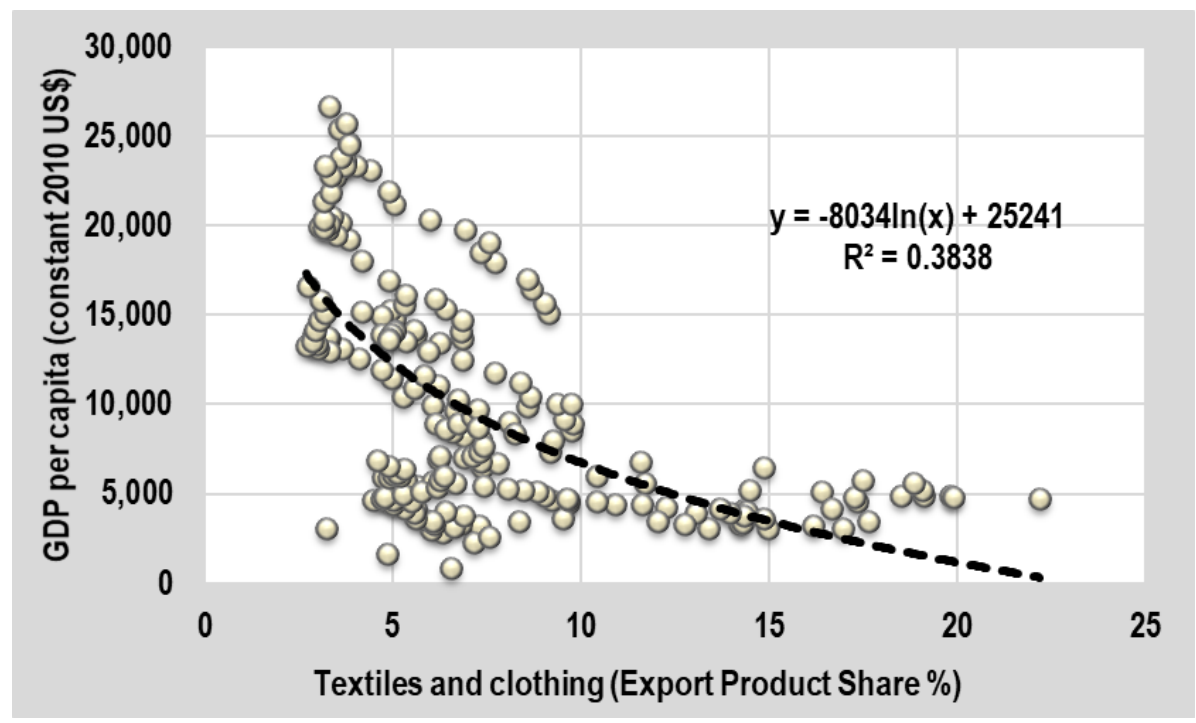

Source: authors based on data World Bank database: World Development Indicators, https://data.worldbank.org/indicator

The results obtained by the Research on the Interdependence of Textiles and Clothing Industry Value Added in Manufacturing on GDP pc, by the Exponential Correlation Procedure showed that the textile industry significantly contributes to GDP pc growth in the early stages of economic development, thus confirming $\mathrm{H} 1$ hypothesis. Also, the obtained results showed that the transition European countries with a lower level of GDP pc have relatively higher share of Textiles and clothing value in the structure of total exports and they confirmed the $\mathrm{H} 2$ hypothesis.

In order for the growth of the textile industry in the so-called countries in late transition is sustainable, it is necessary to encourage the development of activities that create greater added value and increase competitiveness. Therefore, it is necessary to support the development of domestic companies, 
as well as the arrival of those foreign investments that generate higher levels of added value. This would also be a signpost in which direction further research on the development of the textile industry in these countries would need attention.

\section{Conclusion}

At the beginning of the observation period (1995), the nine selected countries in transition were at different levels of economic development. After more than 20 years of transition processes, all observed countries recorded economic growth that was stronger than the average growth in the EU and in the world. Relatively fast growth has enabled these countries to reduce the lag in the level of GDP per capita compared to the EU average. Five out of nine observed countries (Slovenia, the Czech Republic, Hungary, Croatia and Romania) were above the world average in terms of GDP per capita.

The achieved economic growth of GDP per capita was accompanied by a pronounced trend of deindustrialization in most of the observed countries (Serbia, North Macedonia, Croatia, Romania and Slovenia). Similar negative trends were noted in terms of changing the importance of Textiles and clothing in creating value added in manufacturing, i.e., the economy as a whole. In order to illustrate, it can be said that only two (North Macedonia and Serbia) of the observed countries increased their participation, which indicates a decline in the importance of Textiles and clothing in most of the observed economies at the end of 2018.

These changes in economic growth are accompanied by changes in foreign trade activity, which is clearly reflected in the dynamic growth of exports (measured by the Value index of exports) and the growing importance of exports of goods and services in creating GDP. In 2018, the largest growth in exports compared to the base year of 2000 was achieved by Serbia, followed by Romania, the Czech Republic and Bulgaria and Bosnia and Herzegovina. The growth in the value of exports also influenced the change in the share of exports of goods and services in GDP. The largest increases were recorded in Hungary, Serbia, Slovenia and the Czech Republic, and the smallest in Croatia, Bosnia and Herzegovina and Romania. Accordingly, in 2018, the largest share of exports of goods and services in GDP have Hungary, Slovenia and the Czech Republic, which indicates that their development in the transition period of these countries was largely based on strengthening trade competitiveness. 
The textile industry sector (Textile fibers, yarn, fabrics and clothing) also contributed significantly to the significant export expansion of the observed countries (except Slovenia), with the largest increase in the value of textile industry exports recorded by the Czech Republic and Romania in the period 1995-2018. However, despite these trends in 2018, only the Bulgarian Textile industry had a surplus in foreign trade with other countries, unlike in 1995, when Croatia, North Macedonia, Slovenia, Romania and Bulgaria also recorded a surplus in the textile industry.

Also, the results of the study of the interdependence of Textiles and clothing industry Export Product Share and GDP pc, obtained by logarithmic correlation show that the textile industry maximizes its export potential at lower levels of GDP pc, which is consistent with previously obtained results showing that the contribution of textile industry economic growth is higher in the earlier stages of economic development, and that this impact relatively decreases with the growth of GDP pc in these countries.

\section{References}

Adhikari, R., \& Yamamoto, Y. (2007). The Textile and Clothing Industry: Adjusting to the Post-Quata World, Industrial Development for the 21 st Century: Sustainable Development Perspectives. New York: United Nations, 183-234

Ćorovic, E., Jovanovic, P., \& Ristic, L. (2013). Current Trends on the World Textile Market and the Competitiveness of the Serbian Textile Industry, Lodz, Fibres\&Textiles in Eastern Europe, 5(101), 8-12.

Ćorović E., Gligorijevic, Ž., \& Kostadinović, I. (2020). Export Competitiveness of Textile and Clothes of Western Balkan Countries. Fibres \& Textilesin Eastern Europe 28, 4(142): 8-14. DOI: 10.5604/01.3001.0014.0927

Ćorović, E. (2012). Uloga tekstilne industrije u procesu strukturnog prilagođavanja privrede Srbije, doktorska disertacija, Niš: Univerzitet u Nišu, Ekonomski fakultet.

Despotovic, D. Z., Cvetanović, S. Ž., \& Nedić, V. M. (2014). Innovativeness and competitiveness of the Western Balkan countries and selected EU member states. Industrija, 42(1). https://doi.org/10.5937/industrija42-4602

Fischer, A., \& Pascucci, S. (2017). Institutional incentives in circular economy transition: The case of material use in the Dutch textile industry. Journal of Cleaner Production,155, 17-32. DOI:10.1016/j.jclepro.2016.12.038

FIT (2017). Clothing and textile sector in Finland. Flanders Investment \& Trade. Helsinki.

URL: https://www.flandersinvestmentandtrade.com/export/sites/trade/files/market_stud ies/Clothing\%20and\%20textile\%20sector_Finland_2017.pdf. Accessed: 22 Januar 2021

Gligorijevič, Ž., \& Ćorović, E. (2020). Competiteveness of the Textile Industry of the Republic of Serbia on the EU Market.Econimic Themes, 58(1): 1-16. DOI: 10.2478/ethemes-2020-0001 
Gligorijević, Ž. (2019). Ekonomika industrije, Niš: SVEN.

Kathuria, V. (2001). Foreign Firms, Technology Transfer and Knowledge Spillovers to Indian Manufacturing Firms: A Stochastic Frontier Analysis. Applied Economics. 33. 625-42. DOI: $10.1080 / 00036840121940$.

Kostić, V., Milutinović, M., \& Nikolić, M. (2018), Development Performance of Textile Industry of Serbia, Economic Themes, 56 (4), 487-502 DOI: https://doi.org/10.2478/ethemes-2018-0028

Ku, C. C., Chien, C. F., \& Ma, K. T. (2020). Digital transformation to empower smart production for Industry 3.5 and an empirical study for textile dyeing. Computers \& Industrial Engineering, 142, DOI: https://doi.org/10.1016/j.cie.2020.106297.

Lin, B. \& Bai, R. (2020). Dynamic energy performance evaluation of Chinese textile industry. Energy, 199, DOI: 10.1016/j.energy.2020.117388

Mićić, V. (2015). Ponovna industrijalizacija i strukturne promene u funkciji ekonomskog razvoja Republike Srbije. Ekonomski horizonti, 17(1), 15-31, DOI: doi:10.5937/ekonhor1501015M

Shishoo, R. (2012). The importance of innovation-driven textile research and development in the textile industry. In The Global Textile and Clothing Industry (pp. 55-76). Woodhead Publishing.

Urošević, S., Đorđević, D., \& Cvijanović, J. (2009) Značaj doradnih poslova za razvoj tekstilne i odevne industrija Srbije u procesu tranzicije, Industrija, 37(2), 97-125,

World Bank. (n.d.). World Development Indicators. Retrieved March 02, 2021, from https://data.worldbank.org/indicator

Yang, Y., Zhong, C. (1998). China's Textile and Clothing Exports in a Changing World Economy, The Developing Economies 36(1), 3-23. DOI: https://doi.org/10.1111/j.1746-1049.1998.tb00858.x 